\title{
EKSTRAK DAUN SALAM DALAM MENINGKATKAN EKSPRESI FIBROBLAST GROWTH FACTOR PADA ULKUS TRAUMATIK RONGGA MULUT
}

\author{
HN. Amrina Rosada*, Rochman Mujayanto**, Adisty Restu Poetri*** \\ *Program Pendidikan Sarjana Kedokteran Gigi Fakultas Kedokteran Gigi UNISSULA \\ ${ }^{* *}$ Departemen IImu Penyakit Mulut Fakultas Kedokteran Gigi UNISSULA \\ **Departemen Periodonsia Fakultas Kedokteran Gigi UNISSULA
}

Correspondence Rochman Mujayanto, Departemen IImu Penyakit Mulut Fakultas Kedokteran Gigi UNISSULA

Email : rochman.mujayanto@unissula.ac.id

\section{Keywords:}

Bay Leaf, Fibroblast

Growth Factor,

Traumatic Ulcer, Wound Healing

\section{ABSTRACT}

Background: Traumatic ulcers are lesions of the oral mucosa caused by mechanical, chemical, and temperature trauma. Traumatic ulcer treatment aims to reduce inflammation, accelerate the healing process, and reduce pain. Bay leaf has anti-inflammatory pharmacological activities. This study aims to determine the effect of bay leaf extract on the expression of fibroblast growth factor in traumatic ulcer oral mucosa in Wistar rats.

Method: This is an experimental research with a post-test only control group design, consisting of four groups with 20 sample of male Wistar rats. All animals were injured using a hot burnisher attached to the labial mucosa for 1 second. The gel was applied twice daily until the $3 r d$ and 5 th day after the ulcer has formed. Rat mucosal tissues were analyzed by immunohistochemical staining for FGF expressions. Statistical analysis using SPSS Mann-Whitney test.

Result: The results showed the mean of cells expressing FGF in the bay gel extract group on the $3 \mathrm{rd}$ and 5 th days were $8.4 \pm 0.8$, and $13.6 \pm 0.5$. Mann Whitney test results showed $\mathrm{P}<0.05$ there is a significant differential expression of FGF traumatic ulcer oral mucosa of experimental animals on days 3 and 5 compared control group.

Conclusion: Bay leaf extract increased FGF expression on days 3 and 5

\section{PENDAHULUAN}

Ulkus rongga mulut adalah peradangan pada bagian mukosa yang disebabkan kerusakan jaringan epitel rongga mulut dan terbukanya ujung saraf. Traumatik berkaitan adanya trauma mekanik, kimia, dan suhu. Gambaran klinis dari ulkus traumatik merupakan lesi sekunder dengan gambaran khas berupa bentuk soliter bulat, berukuran variatif, kedalaman lesi mencapai lamina $\operatorname{propia}^{1,2,3}$.
Proses penyembuhan ulkus traumatik dibagi menjadi 3 tahap, fase inflamasi, proliferasi, dan remodeling. Fase inflamasi dibagi menjadi 2 yaitu fase inflamasi awal dan fase inflamasi akhir ${ }^{4}$. Sel yang berperan penting adalah makrofag. Makrofag diklasifikasikan menjadi 2 yaitu makrofag proinflamasi yang berperan pada fase inflamasi awal dan makrofag antiinflamasi atau pro-angiogenik yang berperan pada fase inflamasi akhir. 
Pada fase inflamasi akhir dimulai dari 48 jam sampai 72 jam setelah lesi muncul. Fase inflamasi akhir ditandai dengan makrofag mengeluarkan faktor pertumbuhan diantaranya TGF- $\beta$, TGF- $\alpha$, FGF, dan VEGF yang menginisiasi fase selanjutnya, fase proliferasi ${ }^{5}$.

Fase proliferasi berlangsung dalam waktu 48 jam pertama sampai hari ke-14 dan berfungsi menutupi luka yang ada dan mengembalikan fungsi dari jaringan ${ }^{6}$. Karakteristik dari fase ini ditandai dengan migrasi sel fibroblas dan deposisi sintesis matriks ekstraseluler. Fase remodeling menjadi fase terakhir dari proses penyembuhan ulkus. Fase ini dapat berlangsung hingga 2 tahun lebih. Pada fase ini terjadi diferensiasi fibroblas menjadi myofibroblas yang mengekspresikan $\alpha$-Smooth Muscle Actin ( $\alpha$ SMA), kolagen tipe III di jaringan ekstraselular digantikan oleh kolagen tipe I yang memiliki kekuatan tarik lebih besar, dan tingkat angiogenesis menurun ${ }^{7}$.

Pada proses penyembuhan luka, diperlukan faktor pertumbuhan, salah satunya Fibroblast Growth Factor (FGF) yang sangat berperan dalam inisiasi fase proliferasi. FGF diproduksi oleh sel makrofag, sel mast, limfosit T, dan sel endotel pada fase inflamasi akhir atau sekitar 48 jam sampai 72 jam setelah luka muncul ${ }^{8}$. FGF berperan dalam proses penyembuhan ulkus yaitu dengan meregulasi dari fungsi selular diantaranya adhesi, proliferisasi, migrasi, dan diferensiasi dari epitelium, fibroblas, jaringan ikat, dan saraf 9 .
Medikasi ulkus dapat menggunakan obat antiinflamasi yaitu NSAID (Nonsteroid AntiInflammatory Drugs) yang bekerja dengan menghambat pengeluaran mediator inflamasi. Peneliti mencoba meneliti mengenai fitofarmakologi yang memiliki aktivitas antiinflamasi salah satunya adalah daun salam, selain itu daun salam dapat mempercepat proses penyembuhan luka karena bersifat antibakteri. Daun salam yang digunakan dalam sediaan gel karena pengobatan ulkus yang efektif untuk mengurangi rasa sakit dan mempercepat penyembuhan yaitu menggunakan obat dengan sediaan gel yang diaplikasikan secara topikal ${ }^{10}$.

Tujuan penelitian ini untuk mengetahui pengaruh gel ekstrak daun salam (Syzygium polyanthum) terhadap ekspresi FGF pada proses penyembuhan ulkus traumatik rongga mulut hewan coba.

\section{METODE PENELITIAN}

Penelitian dimulai dengan disetujuinya penelitian ini oleh Komisi Etik Fakultas Kedokteran Gigi Universitas Islam Sultan Agung Semarang dengan No.103/B.1-KEPK/SA-FKG/VII/2019. Jenis penelitian ini adalah laboratorium true experimental desain post-test only control group.

Pembuatan ekstrak dilakukan dengan daun salam yang masih segar dikeringkan dalam oven sekitar 2-3 hari, setelah itu daun salam yang telah kering dihaluskan menggunakan blender, dan 
didapatkan daun salam yang telah halus dicampurkan dengan etanol $96 \%$ dengan perbandingan 1:9 dengan metode maserasi didiamkan selama 3 hari dan sesekali diaduk selama 15 menit agar tercampur merata. Pada hari ke-3 ampas daun salam yang mengendap disaring agar mendapatkan filtrat, setelah itu filtrat diuapkan ke dalam rotary evaporator sampai menjadi ekstrak kental daun salam. Ektrak daun salam yang telah didapatkan, dicampur dengan larutan carbomer 1,5\% , TEA 1 gram, metil paraben, dan gliserin. Gel ekstrak daun salam dan bahan penambah tersebut diaduk sampai homogen dan merata sampai tidak ada partikel yang berbeda ${ }^{11}$.

Hewan coba yang digunakan pada penelitian ini adalah tikus wistar jantan dengan jumlah total sampel penelitian yaitu 20 tikus Wistar, yang mengacu rumus WHO (1993) ${ }^{12}$. Hewan coba dibagi menjadi 4 kelompok yaitu K1 (Kontrol hari ke-3), K2 (Kontrol hari ke-5), P1 (Perlakuan hari ke-3), dan P2 (Perlakuan hari ke-5). Hewan coba diadaptasi terlebih dahulu selama 5 hari, setelah itu hewan coba diinjeksi ketamin pada bagian paha. Ketamin dicampur akuades dengan perbandingan 7:3 dan setiap ekor diinjeksi $0.3 \mathrm{ml}$ campuran ketamin dan aquades. Aplikasi anestesi topikal menggunakan benzocaine $10 \%$ pada bagian labial, setelah tikus tenang, pada bagian labial hewan coba dibuat perlukaan / pembuatan ulkus menggunakan ujung burnisher bulat berdiameter $2 \mathrm{~mm}$ yang telah dipanaskan sampai merah menyala, dan diaplikasikan pada labial tikus selama 1 detik $^{13}$. Semua hewan coba yang telah dibuat perlukaan selanjutnya dilakukan randomisasi kelompok, dengan membagi kelompok menjadi 4 .

Pembentukan ulkus diamati, dan ulkus terbentuk hari ke-2 setelah perlukaan, selanjutnya setelah pembentukan ulkus, aplikasi bahan dengan gel carbomer sebagai kelompok kontrol, dan gel ekstrak daun salam sebagai kelompok perlakuan. Pengaplikasian gel dilakukan pada pagi dan sore hari sampai hari ke-3 dan ke-5 pasca terbentuk ulkus. Pada hari ke-3 dan ke-5 masing-masing kelompok dikorbankan dengan klorofom peri inhalasi, dan jaringan ulkus diambil. Pembuangan limbah diserahkan kepada manajemen Laboratorium Hewan Coba Fakultas Kedokteran Unissula.

Jaringan yang telah didapatkan dibuat preparat sediaan histopatologi dan pewarnaan immunohistokimia anti-FGF. Ekspresi FGF didapatkan dari hasil perhitungan rata-rata sel leukosit yang mengekspresikan FGF dengan mikroskop perbesaran 400 kali. Hasil positif jika ditemukan inti sel yang besar dengan sitoplasma berwarna kecoklatan atau hitam keunguan. Hasil negatif jika ditemukan inti sel yang kecil atau besar dengan sitoplasma berwarna kebiruan atau jernih. 
Penghitungan dengan merata-rata jumlah sel leukosit yang mengekspresikan FGF dalam 5 lapang pandang ${ }^{14}$.

\section{HASIL PENELITIAN}

Hasil penelitian pengaruh gel ekstrak daun salam terhadap ekspresi FGF disajikan dalam tabel 1. Tabel 1 menunjukkan jumlah rerata ekspresi FGF kelompok ektrak daun salam lebih tinggi jika dibandingkan dengan kelompok kontrol, Diketahui kelompok perlakuan hari ke-5 memiliki rerata ekspresi FGF tertinggi dan kontrol hari ke-3 dengan rerata ekspresi FGF terendah.

Analisis data dilanjutkan dengan uji normalitas yang didapatkan beberapa kelompok data tidak terdistribusi normal dengan $\mathrm{p}<0.05$ dan uji homogenitas levene test didapatkan data homogen dengan $p>0.05$ maka analisis dilakukan menggunakan uji Mann-Whitney dengan hasil sebagai berikut.

Hasil uji Mann Whitney pada tabel 2 menunjukkan nilai 0.007 pada hari ke-3 dan 0.006 pada hari ke-5 $(\mathrm{P}<0.05)$ yang diartikan terdapat perbedaan yang signifikan pemberian gel ekstrak daun salam terhadap ekspresi FGF pada ulkus traumatik pada hewan coba.

Pembacaan preparat hasil penelitian ditemukan inti sel dengan sitoplasma berwarna kecoklatan pada preparat histologi yang menunjukkan sel tersebut mengekspresikan FGF (Gambar 1).

\section{DISKUSI}

Pada penelitian ini, gel ekstrak daun salam secara signifikan meningkatkan ekspresi FGF pada ulkus mukosa hewan coba. Pada proses penyembuhan luka, fase inflamasi akhir berlangsung pada hari ketiga pasca luka, sel-sel leukosit akan mengekspresikan FGF yang meningkat sampai dengan fase proliferasi, dan menurun saat fase remodeling ${ }^{15}$. Aktivitas maksimal dari growth factor rata-rata berlangsung 3-7 hari pasca luka ${ }^{14}$. Hal ini sesuai dengan penelitian yang dilakukan, yaitu terjadi peningkatan ekspresi FGF dari hari ketiga sampai hari kelima pasca luka. Hasil penelitian didapatkan data beberapa kelompok tidak terdistribusi normal. Hal tersebut dapat terjadi karena tingkat metabolisme obat dari hewan coba yang berbeda, sehingga dapat mempengaruhi data ekspresi FGF yang tidak normal.

Gambar 1 menunjukkan ekspresi FGF masingmasing kelompok pada hari 3 dan 5. Didapatkan sel yang mengekspresikan FGF lebih kuat pada kelompok perlakuan dengan inti sel yang besar dan sitoplasma berwarna kecoklatan atau hitam keunguan. Ekspresi FGF yang tinggi berkorelasi dengan peningkatan proliferasi sel fibroblast dan sel endotel, sedangkan kurangnya ekspresi FGF mengakibatkan penurunan proliferasi fibroblas dan 
angiogenesis, serta mengakibatkan proses penyembuhan luka yang lama ${ }^{9}$. Fibroblast growth factor diproduksi oleh sel makrofag antiinflamasi (M2), sel mast, limfosit $\mathrm{T}$, dan sel endotel. Mekanisme kerja FGF yaitu berikatan dengan reseptor FGFRs dipermukaan sel target (sel endotel, sel epitel, sel fibroblast, dan keratinosit) dan mengaktifkan kaskade biokimia dengan dimulainya mengaktifkan PI3-kinase, mengaktivasi jalur Rac1, dan Rac1 meregulasi aktivasi jalur JNK sehingga mempengaruhi transkripsi inti sel dan menyebabkan terjadinya proliferasi, differensiasi, migrasi sel fibroblast, dan angiogenesis ${ }^{9}$. Terdapat dua macam FGF yang diekspresikan, yaitu FGF profibrotic dan antifibrotic. FGF profibrotic bekerja dengan meningkatkan proliferasi dan migrasi fibroblast dan kolagen, sedangkan FGF antifibrotic bekerja menghambat dan mengurangi proliferasi, migrasi fibroblast dan kolagen dengan mengurangi produksi sel $\alpha$-SMA cells. Produksi FGF profibrotic dan antifibrotic sebagai bentuk kompensasi satu sama lain agar diproduksi secara tidak berlebihan, dan menjaga kestabilan proses penyembuhan luka ${ }^{16}$.

Kandungan di daun salam yang dapat mempengaruhi percepatan proses penyembuhan luka diantaranya minyak atsiri, flavonoid, tanin, vitamin $A$, vitamin $C$, protein, zink, vitamin $B$ kompeks, dan karbohidrat. Essential oil memiliki fungsi dengan mengurangi penyebaran bakteri pada bagian luka[17]. Flavonoid memiliki aktivitas antiinflamasi yang dapat menurunkan sekresi sitokin proinflamasi dan meningkatkan sitokin antiinflmasi ${ }^{18}$. Tanin sebagai antibakteri sehingga proses penyembuhan luka lebih cepat karena mengurangi pertumbuhan bakteri penyebab inflamsi ${ }^{19}$

Vitamin A dan C berperan mempercepat proses inflamasi ke proliferasi dan remodeling dengan meningkatkan jumlah sel yang mengekspresikan FGF sehingga dapat memodulasi aktivitas fibroblas, sel epitel, sel endotel, melanosit, proses epitelisasi, dan sintesis kolagen ${ }^{20}$.Protein berfungsi sebagai biokatalisator deferensiasi sel makrofag dan sel mast. Sel makrofag berdiferensiasi dari makrofag proinflamasi ke makrofag antiinflamasi yang terjadi pada fase inflamasi akhir. Makrofag antiinflamasi akan mengeluarkan berbagai growth factor, salah satunya FGF untuk menginisisasi fase selanjutnya, yaitu fase proliferasi ${ }^{21}$. Kekurangan protein akan menyebabkan transkipsi mRNA dalam sel mast terganggu, proses penyembuhan luka yang lama, persistensi makrofag proinflamasi, penyembuhan luka buruk, dehiscence luka, dan produksi kolagen yang tidak adekuat ${ }^{22}$. 
Zink mempengaruhi RNA polymerase, DNA polymerase, dan DNA transkriptase. Pelepasan ion zink akan mempengaruhi ekspresi FGF di makrofag, sel mast, dan sel $T$ yang akan meningkatkan proliferasi fibroblast dan migrasi keratosit pada fase proliferasi ${ }^{23}$. Vitamin Bkompleks yang terkandung di daun salam (niasin, tiamin, riboflavin, asam folat, dan B12) merupakan kofaktor dalam sintesis DNA.
Vitamin B-kompleks memiliki pengaruh pada perubahan morfologi dan pembelahan sel, salah satunya sel pada mukosa. Vitamin Bkompleks berperan dalam metabolisme nukleotida. Nukleotida mempengaruhi sintesis protein salah satunya faktor pertumbuhan yaitu FGF24. Karbohidrat menstimulasi makrofag antiinflamasi, sel mast, dan limfosit T mensekres

\begin{tabular}{|c|c|c|c|c|}
\hline Kelompok & $\begin{array}{l}\text { Kontrol hari } \\
\text { ke-3 } \\
\text { (K1) }\end{array}$ & $\begin{array}{c}\text { Kontrol hari } \\
\text { ke-5 } \\
\text { (K2) }\end{array}$ & $\begin{array}{l}\text { Perlakuan } \\
\text { hari ke-3 } \\
\text { (P1) }\end{array}$ & $\begin{array}{c}\text { Perlakuan } \\
\text { hari ke-5 } \\
\text { (P2) }\end{array}$ \\
\hline $\begin{array}{l}\text { Jumlah } \\
\text { sampel }\end{array}$ & 5 & 5 & 5 & 5 \\
\hline Rerata & $2,2 \pm 0,8$ & $3,2 \pm 0,4$ & $8,4 \pm 0,8$ & $13,6 \pm 0,5$ \\
\hline \multicolumn{5}{|c|}{ Tabel 2. Hasil uji Mann-Whitney } \\
\hline Hari ke- & Kelompok & $\mathbf{P}$ & $\begin{array}{c}\text { Sig } \\
<0.05\end{array}$ & Hasil \\
\hline \multirow[t]{2}{*}{3} & $\begin{array}{c}\text { Kontrol } \\
\text { (K1) } \\
\end{array}$ & \multirow[t]{2}{*}{0.007} & \multirow[t]{2}{*}{$\mathrm{P}<0.05$} & \multirow[t]{2}{*}{ Signifikan } \\
\hline & Perdakuan (P1) & & & \\
\hline \multirow[t]{2}{*}{5} & $\begin{array}{c}\text { Kontrol } \\
\text { (K2) }\end{array}$ & \multirow[t]{2}{*}{0.006} & \multirow[t]{2}{*}{$\mathrm{P}<0.05$} & \multirow[t]{2}{*}{ Signifikan } \\
\hline & $\begin{array}{l}\text { Perlakuan } \\
\text { (P2) }\end{array}$ & & & \\
\hline
\end{tabular}
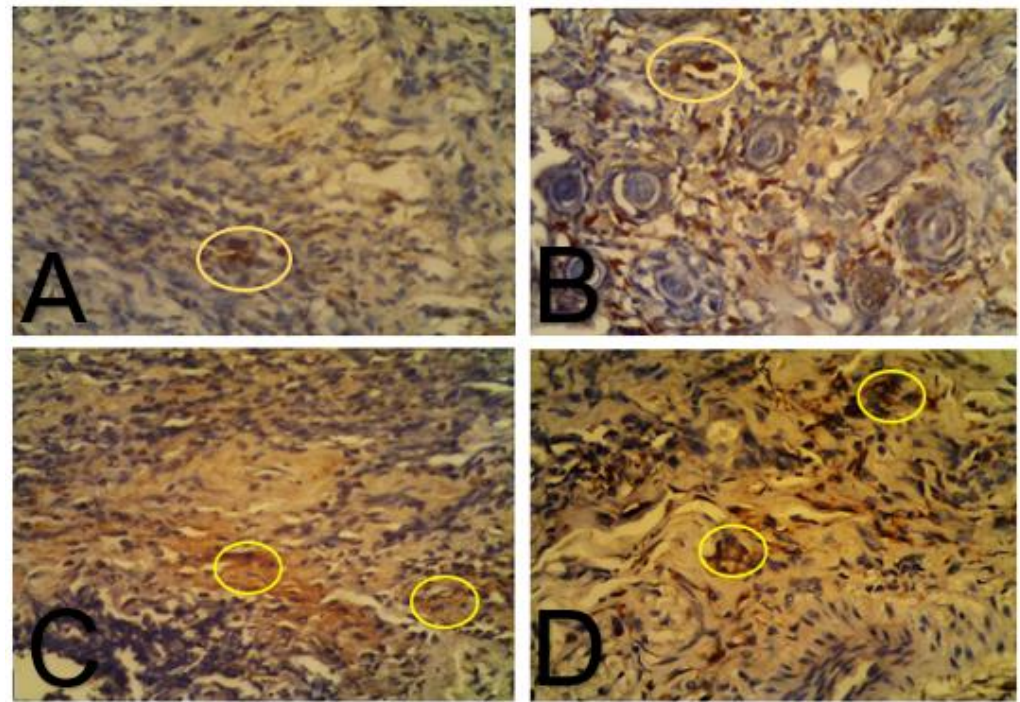

Gambar 1. Gambaran sel yang mengekspresikan FGF berwarna kecoklatan pada kelompok kontrol hari 3 (a); kelompok kontrol hari 5 (b); kelompok perlakuan hari 3 (c); dan kelompok perlakuan hari 5 (d) yang diamati dengan mikroskop perbesaran 400x. 
hormon dan growth factor saat proses penyembuhan luka, salah satunya FGF, sehingga meningkatkan produksi sel fibroblast saat fase proliferasi berlangsung ${ }^{20}$.

\section{KESIMPULAN}

Kandungan daun salam mampu meningkatkan jumlah sel yang mengekspresikan FGF dibanding dengan kelompok kontrol. Banyaknya jumlah sel yang mengekspresikan FGF akan meningkatkan kadar FGF dalam jaringan, dan dapat mempercepat proses proliferasi, diferensiasi, dan migrasi sel fibroblast, sehingga fase proliferasi berjalan dengan baik dan proses penyembuhan luka menjadi lebih cepat.

\section{DAFTAR PUSTAKA}

1. Bakar A. Kedokteran Klinis. 2nd ed. Jakarta: Quantum Sinergis Media; 2012.

2. Bombeccari GP, Guzzi G, Pallotti F, Porrini $M$, Giannì $A B$, Spadari $F$. Large oral ulcer of tongue related to dental trauma. Stomatol Balt Dent Maxillofac J. 2017;19(19):51-4.

3. Harty F., Ogston R, Sumawinata N. Kamus Kedokteran Gigi. Jakarta: EGC; 2012.

4. Sherwood L. Fisiologi Manusia dari Sel ke Sistem. 8th ed. Jakarta: EGC; 2016.

5. Chakrabarti S, Bhattacharya R, Deb K. Cell-based Wound Healing: Mechanisms and Treatments. $\mathrm{Br} \mathrm{J}$ Med Med Res. 2016;11(4):1-17.

6. Keast D, Forest- L, Forest-lalande L. Basic Principles of Wound Healing (An understanding of the basic physiology of wound healing provides the clinician with the framework necessary to implement the basic principles of chronic wound care). 2011;9(2):1-5

7. Landén NX, Li D, Ståhle M. Transition from inflammation to proliferation: a critical step during wound healing. Cell Mol Life Sci. 2016;73(20):3861-85.

8. Spaccapelo L. Rationale For Basic Fgf In Wound Healing And Review Of. 2016;3(5):51-9.

9. Yun YR, Won JE, Jeon E, Lee S, Kang W, Jo $\mathrm{H}$, et al. Fibroblast growth factors: Biology, function, and application for tissue regeneration. $\mathrm{J}$ Tissue Eng. 2010;1(1):1-18.

10. Westby MJ, Dumville JC, Soares MO,Stubbs N NG. Dressings and Topical Agents for Treating Pressure Ulcers. London: Wiley; 2017.

11. Megawati, Roosevelt A, Akhir L. Formulasi Dan Uji Stabilitas Fisik Sediaan Gel Ekstrak Kulit Buah Rambutan (Nephelium lappaceum L.) Sebagai Obat Sariawan Menggunakan Variasi Konsentrasi Basis Carbopol. [JFS] J Farm Sandi Karsa. 2019;5(1):5-10.

12. Sastroasmoro $S$, Ismael $S$. Dasar Metodologi Penelitian Klinis. Jakarta: Sagung Seto; 2011.

13. Mujayanto R. Pengaruh Zink Sulfat 1\% Topikal Terhadap Jumlah Makrofag Ulkus Traumatikus Mulut Tikus Wistar Diabetes. Universitas Airlangga; 2016.

14. Destri C, Sudiana IK, Nugraha J. Potensi Ekstrak Jatropha Multifida Terhadap Ekspresi Vegf Aphthous Ulcer Rat norvegicus. 2017;1(2):59-65.

15. Park JW, Hwang SR, Yoon I-S. Advanced Growth Factor Delivery Systems in Wound Management and Skin Regeneration. Molecules. 2017 Jul;22(8):1259.

16. Dolivo DM, Larson SA, Dominko $T$. Fibroblast Growth Factor 2 as an Antifibrotic: Antagonism of Myofibroblast Differentiation and Suppression of ProFibrotic Gene Expression. Cytokine Growth Factor Rev. 2017/09/23. 2017 Dec;38:49-58.

17. Muhammad IR, Hariandja EM. Review: Aktivitas Farmakologis, Senyawa Aktif, dan Mekanisme Kerja Daun Salam ( Syzygium polyanthum ). Perkemb Terkini 
Sains Farm dan Klin. 2015; (November 2015):6-7.

18. Silalahi M. Syzygium polyanthum (Wight) Walp. (Botani, Metabolit Sekunder dan Pemanfaatan). J Din Pendidik. 2017;10(1):1-16.

19. Agustina R, Indrawati DT, Masruhin MA. Aktivitas Ekstrak Daun Salam (Eugenia Polyantha) Sebagai Antiinflamasi Pada Tikus Putih (Rattus Norvegicus). Lab Penelit Dan Pengemb Farmaka Trop Fak Farm Univ Mulawarman, Samarinda, Kalimantan Timur. 2015;120-3.

20. Barchitta M, Maugeri A, Favara G, San Lio RM, Evola G, Agodi A, et al. Nutrition and wound healing: An overview focusing on the beneficial effects of curcumin. Int J Mol Sci. 2019;20(5).
21. Mackay E. The Power of Protein in Wound Healing. Wound Care Canada. 2019;17(1):34-7.

22. Dewi S, Soemardini $S$, Nugroho FA. Hubungan Tingkat Konsumsi Protein, Zat Besi (Fe) dan Zinc (Zn) dengan Kondisi Penyembuhan Luka Perineum Derajat II pada Ibu Nifas. Maj Kesehat. 2016 Sep;3:137-43.

23. Anggraeni D, Adji D, Murwanti R. Kesembuhan Luka Setelah Pemberian Topikal ZINK pada Tikus dengan Pakan Lemak Tinggi. J Kedokt Hewa. 2015;1058.

24. George J, Shobha R, Lazarus F. Folic acid: A positive influence on periodontal tissues during health and disease. Int $\mathrm{J}$ Heal Allied Sci. 2013 Jul;2(3):145-52. 